Ananias Francisco Dias Júnior ${ }^{1+}$, Richard Briques Anuto², Carlos Rogério Andrade ${ }^{3}$, Natália Dias de Souza ${ }^{4}$, Saly Takeshita ${ }^{5}$, José Otávio Brito', Adriana Maria Nolasco'

\title{
INFLUENCE OF Eucalyptus WOOD ADDITION TO URBAN WOOD WASTE DURING COMBUSTION
}

Keywords:

Combustion index

Waste utilization

Eucalyptus wood for energy

Historic:

Received 25/03/2017

Accepted 26/12/2017

Palavras chave:

Índice de combustão

Aproveitamento de resíduos

Madeira de eucalipto para energia

+Correspondence: ananiasjr@usp.br

DOI:
ABSTRACT: This research analyzed the effect of the addition of $E$. grandis $x E$. urophylla wood to the wood waste of urban origin (WWU) as a strategy for energy generation. The WWU was collected in transshipment and from a sorting company of civil construction waste in the city of Piracicaba, SP. The wood of eucalyptus was obtained from a 7-year old plantation. Five treatments with proportions (\%) of WWU and eucalyptus wood were analyzed: $\mathrm{TI}=100 / 0, \mathrm{~T} 2=75 / 25, \mathrm{~T} 3=50 / 50, \mathrm{~T} 4=25 / 75$ and $\mathrm{T} 5=0 / 100$. The treatments had the physical, chemical, immediate characteristics, mineral contaminants rate, and combustion test (ICOM) analyzed. The data were analyzed through the study of variance, correlations, and multivariate hierarchical clusters analysis (HCA). The higher content of extractives, holocellulose, volatile materials, low ash content values, rate of mineral contaminants and high performance for combustion test were observed only for the treatment having exclusively eucalyptus wood (T5). However, the addition of eucalyptus wood in the WWU allowed for the increase of the ICOM of these materials. In this way, the T3 treatment presents as the most recommended for energetic use.

\section{INFLUÊNCIA DA ADIÇÃO DE MADEIRA DE EUCALIPTO À RESÍDUOS MADEIREIROS URBANOS FRENTE À COMBUSTÃO}

RESUMO: Este estudo analisou o efeito da adição de madeira de $E$. grandis $\times E$. urophylla à resíduos madeireiros de origem urbana (RMOU) como estratégia para geração de energia. Os RMOU foram coletados em uma empresa de transbordo e triagem de resíduos da construção civil (RCC) no município de Piracicaba, SP e a madeira de eucalipto foi obtida a partir de um plantio de sete anos de idade. Foram analisadas cinco tratamentos com proporções (\%) de RMOU e madeira de eucalipto, sendo $\mathrm{TI}=100 / 0, \mathrm{~T} 2=75 / 25, \mathrm{~T} 3=$ $50 / 50, T 4=25 / 75$ e T5 $=0 / 100$. Desses tratamentos foram analisadas as características físicas, químicas, imediatas, taxa de contaminantes minerais e teste de combustibilidade (ICOM). Os dados foram analisados por meio da análise da variância, correlações e análise multivariada de agrupamento hierárquico (cluster). Observou-se que elevados teores de extrativos, de holocelulose, de materiais voláteis, assim como baixos teores de cinza e de contaminantes e o melhor desempenho da combustão foram para o tratamento com $100 \%$ de madeira de eucalipto (T5). Por outro lado, a adição de madeira de eucalipto aos RMOU possibilitou o incremento do ICOM. Dessa forma, o tratamento T3 é o mais recomendado para a utilização energética.

\footnotetext{
' University of Sao Paulo - Piracicaba, São Paulo, Brazil

${ }^{2}$ Faculty of Technology of São Paulo - São Paulo, São Paulo, Brazil

${ }^{3}$ Goias Federal University - Jataí, Goiás, Brazil

${ }^{4}$ Federal Rural University of Rio de Janeiro - Seropédica, Rio de Janeiro, Brazil

${ }^{5}$ Federal University of Sergipe - Aracaju, Sergipe, Brazil
} 


\section{INTRODUCTION}

Urban solid waste, in general, is represented by paper, glass, wood, plastics, and organic material. Most of these wastes are allocated without any treatment, the most common destinations being landfills for civil works, landfills, recycling stations, and irregular deposition (MMA, 2009).

Among the discarded materials, wood waste consists mainly of pallet wood, construction timbers, and other woods mixed with other solid urban waste (ATKINS; DONOVAN, 1996). Often, there can be other materials attached to waste, such as additives, preservatives, dyes, resins, varnishes, adhesives, cement, mortar, metallic materials (nails, hinges, etc.), paper, cardboard, waxes, and adhesives (WIECHETECK, 2009; REMADE SCOTLAND, 2004).

Within the possible routes for recovery of urban wood waste (WWU), energy production is proposed because the scale of generation of this waste and scale of use as an energy source. However, there is a need for more in-depth knowledge of the chemical composition of WWU. This is due to the large number of possible contaminants that may result in the emission of "black carbon", contributing to global warming and to serious deleterious effects on human health (KROOK et al., 2006; BOND et al., 20I3).

Depending on the variations in the WWU composition, the energy characteristics may vary. The presence of waterproofing materials and some types of glue, i.e., can facilitate combustion, increasing the temperature and emissions of gases, such as $\mathrm{CO}_{2}, \mathrm{CO}$, $\mathrm{SO}_{2}$, and $\mathrm{NO}$, during the process (FIDAN et al., 20l6).

The use of WWU for energy production purposes can provide environmental, economic, and social benefits to municipalities. Environmental benefits, given the appropriate and controlled disposal of the waste, reduce its volume and avoid the disposal in irregular areas or its burning in the open, which can otherwise result in public health and urban spacing problems. Economic and social benefits, as it constitutes an energy feedstock, include low costs and easier production with great potential for aggregation of value in different productive chains, in addition to being a source of new ventures, jobs, and income (WIECHETECK, 2009; NOLASCO; ULIANA, 20I4).

However, homogeneity is one of the recommended characteristics for energy materials from the technical point of view (KRISTJANSSON et al., 2016). Materials with very variable composition and characteristics are difficult to control, influencing the resultant heat generation and transfer.
The combustion index (ICOM) is an appropriate indicator for assessing the quality of wood-based materials for energy use because it integrates the combustion time, the temperature reached, and the mass consumed to generate it in a single value (QUIRINO; BRITO, I991; DIAS JÚNIOR et al., 20I5), allowing for inference about its performance as a fuel.

The characterization of the WWU can also contribute to directing materials for more promising uses, e.g., for the generation of electric energy (REIS, 2015). According to the author, this application has been restricted to small scale enterprises, but its impact on the energy matrix is expected to increase over time, being motivated by the sheer volume available, low cost, and proximity of generation and local use.

In Sweden, solid waste already accounts for almost $60 \%$ of the energy used in heating systems in urban buildings (KROOK et al., 2006). In addition, its use in steam generation using boilers, alembic furnaces, forges, and potteries could be easily made possible (DIAS JÚNIOR et al., 2014).

Considering the need to improve the characteristics and composition of the WWU for the adaptation to the energy utilization, this study investigated the hypothesis that the addition of a more homogeneous material to the WWU can influence its combustion process, enabling its valorization.

Thus, this research aimed to analyze the effects of the addition of Eucalyptus sp. wood chips to WWU, making them more homogeneous and improving their energy characteristics for combustion.

\section{MATERIAL AND METHODS}

\section{Sampling and preparation of materials}

Eucalyptus grandis $x$ Eucalyptus urophylla wood was obtained from an experimental a 7 year-old experimental crop, transformed into chips, and homogenized in a 30 $\mathrm{mm}$ (that passed the sieve).

Waste wood of urban origin (WWU) was collected at a Recycling Plant in the Piracicaba, SP city, Brazil, through a sampling carried out according to NBR 10.007 (ABNT, 2004). The WWU was composed of $56 \%$ solid wood and $44 \%$ of reconstituted wood panels (particleboards, medium density fiberboards, plywoods). The materials were dried at $103 \pm 2{ }^{\circ} \mathrm{C}$ until the mass was constant. Afterwards, the WWU passed through a mat equipped with magnetic plate to remove any adhered metals while still in the Recycling Plant and, subsequently, it was processed into chips and homogenized with a 30 $\mathrm{mm}$ mesh screen. 
In order to evaluate the hypothesis of obtaining a better fuel with the addition of $E$. grandis $\times E$. urophylla wood in the composition, the following treatments were formulated:

TI: $100 \%$ WWU chips and 0\% eucalyptus wood chips.

T2: $75 \%$ WWU chips and 25\% eucalyptus wood chips.

T3: $50 \%$ WWU chips and 50\% eucalyptus wood chips.

T4: $25 \%$ WWU chips and $75 \%$ eucalyptus wood chips.

T5: $0 \%$ WWU chips and 100\% eucalyptus wood chips.

Where: WWU = waste wood of urban origin.

\section{Physical, chemical and immediate characterization}

Measurement of bulk density was performed according to standard NBR 6922 (ABNT, 198I), and samples of the industrial chips were processed at the Recycling Plant where the residues were collected.

The T-I2 05-75 (TAPPI, 1975) and 222 05-74 (TAPPI, 1974) standards were used to determine the total extractive and lignin Klason contents, respectively. Holocellulose content was obtained indirectly by subtracting the sum of total extractive contents and lignin content of $100 \%$.

The immediate analysis was carried out to determine the contents of volatile materials, ash, and fixed carbon, according to NBR 8 I I 2 (ABNT, 1986). The higher heating value was determined in a calorimeter of the brand IKA model C-2000, according to the NBR 8633 (ABNT, 1984) standard. The lower heating value was determined using equation [I], where: LHV = lower heating value; $\mathrm{HHV}=$ higher heating value; $\mathrm{H}=$ average moisture, on wet basis (\%).

$L H V_{\text {kcal kg- }}=\{(H H V-25.11 \times H) /[(100+H) \times 100]\}$

The rate of contamination by minerals was determined according to the procedure described by Brito and Ceribelli (2012). I0 g of material from each treatment were used with particle size between 40 and 60 $\mathrm{mm}$. The samples were placed in a $250 \mathrm{ml}$ capacity beaker and filled with $200 \mathrm{ml}$ of distilled water, and the mixture was stirred for one minute. Afterwards, the solution was allowed to stand for two minutes. The supernatant of the solution was collected and dried at $103^{\circ} \mathrm{C}$ until a constant mass was reached. This methodology is applicable when the wood sample "supernatant" from the mixture is free of contaminating minerals due to settling. Ashes were obtained free of contaminants, according to the NBR 8II2 (ABNT, 1986). The contamination rate was then calculated using Equation 2, where: $\mathrm{CR}=$ contamination rate (\%); $A C t=$ total ash content (wood ash + acquired ash/contaminant) (\%); $A C=$ ash content of wood free of contaminating minerals (\%).

$C R(\%)=\frac{A C t-A C}{A C t} \cdot 100$

\section{Combustion test}

In determining the combustion index (ICOM), the procedures followed are described by Quirino and Brito (199I) and Dias Júnior et al. (2015). The treatment samples were homogenized in a $16 \mathrm{~mm}$ mesh sieve and inserted in a $1.25 \mathrm{dm}^{3}$ stainless steel combustor. The apparatus had an aluminum sheet guard that prevented combustion of the incoming air, a digital thermometer for the measurement of temperatures reached during combustion, and a digital scale. The amount of sample used in each replicate was $150 \mathrm{~g} \pm(10 \mathrm{~g})$. The duration of the test is the time required for complete combustion of the material. The temperature and the mass consumed were recorded every minute, from the initial time equal to zero until the final time. The combustion index was calculated using Equation 3, where: $\mathrm{A}=$ Percentage of the test time at which the temperature remained above $150^{\circ} \mathrm{C}$, measured in relation to the total time (minutes) of combustion; $B=$ Percentage of the maximum temperature reached in the test, in relation to the temperature of $150^{\circ} \mathrm{C} ; \mathrm{C}=$ Percentage of the total mass consumed generating temperatures above $150^{\circ} \mathrm{C}$.

$I C O M=\frac{A \times B}{100} \times C$

ICOM ranges from 0 to I (dimensionless) and is intended to identify materials that provide higher temperatures due to the lower mass loss (DIAS JÚNIOR et al., 2015).

\section{Data analysis}

The data were tested for variance (Levene) and normality (Shapiro Wilk). Only ICOM, ANOVA and Scott-Knott were tested for differentiation between the averages. Thus, the construction of the Pearson correlation matrix with direct focus on the combustion of the materials was conducted. Correlations were tested at $95 \%$ probability ( $\mathrm{p}$ value $<0.05$ ). The relationships with high $R$ values, having direct influence on the combustion and easy measurement, were adjusted to improve the quality of the variables involved. 
The multivariate cluster analysis was used for identifying similarity between the treatments studied. Agglomerative hierarchical cluster analysis (HCA) was performed for this purpose. The Manhattan distance was adopted as a measure of proximity, and the method of the average link was used as a technique for grouping similar treatments together (MINGOTI, 2005; MANLY, 2008). The quality of the obtained dendrogram was evaluated by the cophenetic correlation coefficient that measures the correlation between the distances recovered from the dendrogram and the original distances matrix. The importance of this method, according to Manly (2008), is that it is possible to cluster true cluster that do not seem to exist and reduce the number of data in smaller cluster. The arithmetic means of all variables were considered for standardized study with mean 0 and variance I. All analysis were performed using Minitab $16.0^{\circledR}$ software.

\section{RESULTS AND DISCUSSION}

\section{Characterization of material}

According to Table I, there was an increase in bulk density with the increasing proportion of eucalyptus wood. In absolute terms, the lowest value was found for treatment TI (I00\% of WWU), and the highest value for the treatment T5 (100\%) of eucalyptus wood.

Farage et al. (2013) found values for bulk density of MDF (Medium Density Fiberboard) residues to be $303 \mathrm{~kg} \mathrm{~m}^{-3}$ and $200 \mathrm{~kg} \mathrm{~m}^{-3}$ for solid wood with the latter value being close to that found in this research. It was observed that the extractive contents (EC) gradually decreased as the addition of eucalyptus wood increased (Table I). Possibly, the solvents used in the extraction have removed not only extractives, but also any other type of component adhered to materials such as paints, varnishes, and adhesives.
The lignin contents (LC) were higher for the treatments with a higher proportion of WWU (Table I). It is believed that high values of this variable are mainly related to the presence of Pinus sp. panels in WWU, a gymnosperm wood, that have higher lignin contents (about 30\%) when compared to angiosperm woods ( \pm $21 \%$ ) (SOARES et al., 20I4). The holocellulose contents (HC) had an inverse behavior to the lignin contents (Table I). This can be justified by the methodology used, which calculated this variable as a function of the sum of total extractive and lignin contents.

The highest content of volatile materials (VM) was for the T5 treatment. This can be explained by the fact that it is composed of $100 \%$ eucalyptus wood and has not previously suffered any type of thermal treatment (wood sheets, reconstituted panels). Thus, these processes may have contributed to the volatilization of the materials in other treatments. It should be noted that the production of MDP (Medium Density Particleboard) and MDF involves heat and pressure (MATOS et al., 2008). Thus, when there is a need for the presence of flames, the use of fuels with a high content of volatile materials is recommended (DIAS JÚNIOR et al., 20I4). Therefore, treatments with higher proportions of eucalyptus wood would be suggested.

According to the results, the highest fixed carbon (FC) value was for $\mathrm{TI}$ treatment with $100 \% \mathrm{WWU}$ (Table I), and this is a desirable feature for use in direct combustion of biomass (ANDRADE, 1989). As none of the treatments studied underwent any kind of thermal treatment (carbon concentration), this observation emphasizes the hypothesis that the WWU have larger amounts of softwood in their composition, due to the higher carbon content compared to a hardwood like eucalyptus. For this variable (FC), the treatments with larger proportions of WWU presented the highest levels. Therefore, this composition would be better for solid state combustion of the fuel.

TABLE I Average values of the characteristics analyzed in the proposed treatments.

\begin{tabular}{cccccccccccc}
\hline Treatment & $\mathrm{DB}\left(\mathrm{kg} \cdot \mathrm{m}^{-3}\right)$ & $\mathrm{EC}(\%)$ & $\mathrm{LC}(\%)$ & $\mathrm{HC}(\%)$ & $\mathrm{VM}(\%)$ & $\mathrm{AC}(\%)$ & $\mathrm{FC}(\%)$ & $\mathrm{HHV}\left(\mathrm{MJ} \cdot \mathrm{kg}^{-1}\right)$ & $\mathrm{LHV}\left(\mathrm{MJ} \cdot \mathrm{kg}^{-1}\right)$ & $\mathrm{CR}(\%)$ \\
\hline TI & $\mathrm{I} 1$ & 6.73 & 32.22 & $74.5 \mathrm{I}$ & 77.68 & 1.33 & 21.00 & 19.02 & 17.75 & 92.17 \\
S.E. & 0.01 & 0.67 & 1.31 & 1.30 & 1.55 & 0.06 & 1.49 & 0.04 & 0.04 & 1.08 \\
T2 & 212 & 4.70 & 33.31 & 62.22 & 80.48 & 0.74 & 18.78 & 19.07 & 17.85 & 82.26 \\
S.E. & 0.01 & 1.93 & 3.27 & 4.45 & 0.49 & 0.09 & 0.51 & 0.03 & 0.03 & 10.01 \\
T3 & 214 & 4.80 & 30.36 & 74.44 & 80.40 & 0.73 & 18.87 & 19.11 & 17.84 & 79.92 & 0.02 \\
S.E. & 2.99 & 0.95 & 1.39 & 1.89 & 0.20 & 0.08 & 0.24 & 0.02 & 0.03 & 8.20 \\
T4 & 215 & 3.60 & 29.71 & 67.89 & 82.02 & 0.43 & 17.55 & 19.04 & 17.76 & 67.64 \\
S.E. & 3.01 & 0.90 & 2.73 & 1.90 & 0.62 & 0.03 & 0.65 & 0.04 & 0.04 & 18.15 \\
T5 & 250 & 2.53 & 27.42 & 75.11 & 83.97 & 0.12 & 15.90 & 19.07 & 17.80 & 29.90 \\
S.E. & 3.23 & 1.03 & 1.67 & 2.39 & 0.89 & 0.03 & 0.87 & 0.01 & 0.04 & 1.32 \\
\hline
\end{tabular}

Where: Proportion of the WWU/eucalyptus wood (\%): $\mathrm{TI}=100 / 0 ; \mathrm{T} 2=75 / 25 ; \mathrm{T} 3=50 / 50 ; \mathrm{T} 4=25 / 75 ; \mathrm{T} 5=0 / 100 . \mathrm{DB}=$ Density bulk; $\mathrm{EC}=$ extractive content; $\mathrm{LC}=$ lignin content; $\mathrm{HC}=$ holocellulose content; $\mathrm{VM}=$ volatile materials; $\mathrm{AC}=$ Ash content; $\mathrm{FC}=$ fixed carbon content; $\mathrm{HHV}=$ higher heating value; $\mathrm{LHV}=$ lower heating value; $\mathrm{CR}=$ contamination rate; $\mathrm{SE}=$ standard error. 
Regarding the ash content (AC), the highest levels were found for the $\mathrm{TI}$ and $\mathrm{T} 2$ treatments, being $1.33 \%$ and $0.74 \%$, respectively (Table I). Quirino et al. (2004) obtained high ash content in wood residues for the following treatments: MDF, hardboard, uncoated, and wood composite mixtures $(0.97 \%)$, MDF residues $(0.73 \%)$, mixtures of panel waste MDF with and without coating (2.58\%) and blends of MDF, hardboard, and uncoated plywood $(5.02 \%)$. Therefore, it is possible that the panels made with these materials have an effect on $A C$. The higher the $A C$ in the wood fuel, the greater the wear and tear caused by the cutting tools of the chip processing equipment. Thus, the lower this variable, the lower the costs with treatment and final disposal (SOUZA et al., 2009; FARAGE et al., 2013).

The higher heating value $(\mathrm{HHV})$ ranged from 19.02 MJ kg-1 (TI treatment) to 19.1 I $\mathrm{MJ} \mathrm{kg}^{-1}$ (T3 treatment), a difference of less than $2 \%$ between these intervals. The lower heating value (LHV) ranged from $17.75 \mathrm{MJ} \mathrm{kg}^{-1}$ to $17.85 \mathrm{MJ} \mathrm{kg}^{-1}$ between treatment $\mathrm{TI}$ and treatment $\mathrm{T} 2$, respectively (Table I). These results indicate that there were no significant responses of heat energy in the addition of eucalyptus wood to WWU. The higher heating value is related to the high lignin and extractive contents because in these components, there is less oxygen than in the polysaccharides (e. g. holocellulose). However, this relationship was not observed in this study, since the lignin and extractive contents presented variations are not reflected in the heating value (Table I).

The highest contamination rate (CR) was observed in TI treatment (Table I). This value may be due to mineral components adhered to the WWU or soil contact from the floor of the stock yard. WWUs, mainly from civilian buildings, may contain cements, mortars, and other contaminants with high mineral contents. Linked to this, calculation of this variable is performed based on the ash content of the materials. The ash content in eucalyptus wood is relatively low, and thus, its contribution is relatively small in the final result.

Based on the characteristics analyzed, the WWU presented regular values for energy use, and its introduction in the composition of biomass solid fuels is recommended. However, the proportion should be defined according to the final use of the fuel (boiler heating, use in potteries, steam generation, thermoelectricity). For example, the use of WWU results in an increase in lignin and fixed carbon content, desired characteristics for use in combustion. The results obtained in this study demonstrate that the compositions containing equal amounts of WWU and eucalyptus wood presented good results for production of bioenergy. T3 treatment (50\% WWU and $50 \%$ eucalyptus wood) is most favorable to this effect.

\section{Combustibility}

Analysis of the behavior of the treatments can be observed in Figure IA. The maximum temperature reached varied according to the ratio $\mathrm{WWU} /$ wood of eucalyptus, and the same occurred in relation to the time needed to reach this temperature. Figure IB shows the mass loss as a function of time, and Figure 2 shows these differences quantitatively, where: Proportion of WWU/ eucalyptus $\operatorname{wood}(\%): \mathrm{TI}=100 / 0 ; \mathrm{T} 2=75 / 25 ; \mathrm{T} 3=$ 50/50; T4 = 25/75; T5 = 0/100; where: T. Máx. e T. F. $=$ Maximum temperature and final temperature measured during the combustion test, respectively. Proportion of WWU/eucalyptus wood (\%): $\mathrm{TI}=100 / 0 ; \mathrm{T} 2=75 / 25$; $\mathrm{T} 3=50 / 50 ; \mathrm{T} 4=25 / 75 ; \mathrm{T} 5=0 / 100$. Average values followed by the same letter do not differ by the ScottKnott test at $5 \%$ significance.
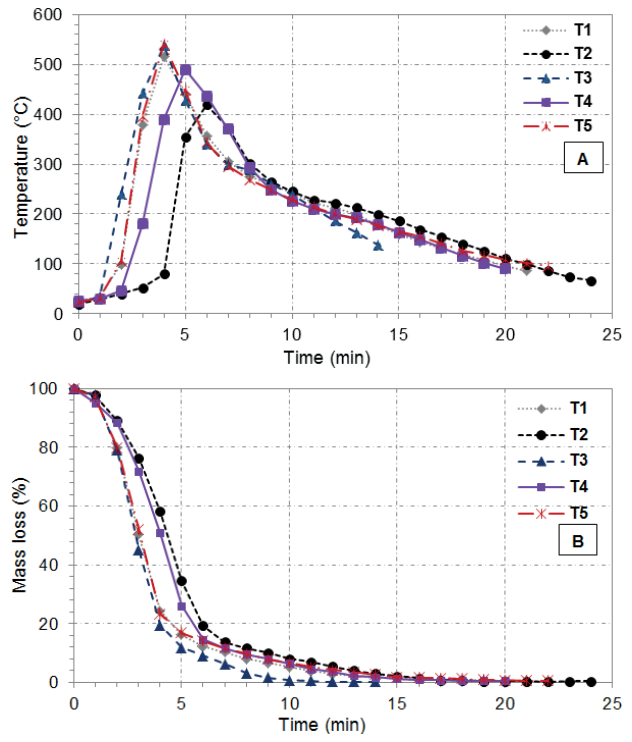

FIGURE I Variation of temperature (A) and mass consumption (B) during the combustion test.

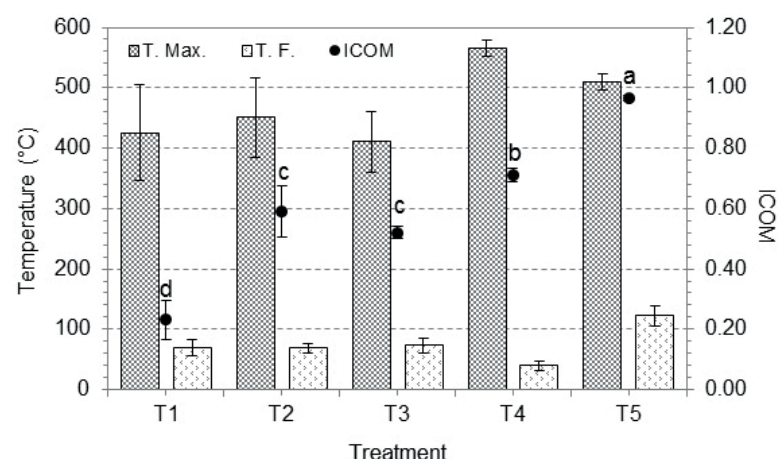

FIGURE 2 Combustion index for the analyzed treatments. 
The better understanding of the behavior of the different compositions discussed below, needs to consider the three main combustion phases according to Calvo et al. (20।4): i) first stage: it is the initial heating accompanied by drying of the material and commencement of nonvolatilization without the existence of a visible flame, resulting in relatively low mass loss of the fuel; ii) second stage: this includes non-volatilization, ignition, combustion of volatile compounds, and initiation of charcoal formation, presenting rapid mass loss and a vigorous flame; and iii) third stage: the mass loss of of the fuel is very low, corresponding to the combustion of the charcoal with only small visible flames. Considering the temperatures for these phenomena, the phases can be deduced based on Figure IA and Figure IB.

According to Figure IA, the highest temperature was observed for the T5 treatment (100\% eucalyptus wood), followed by the T3 treatment (50\% WWU and $50 \%$ eucalyptus wood). However, the treatment composed of $75 \%$ WWU (T2) had the lowest mass loss and it was better uniformed during this assay (Figure IB). Paula et al. (20II), evaluating the ICOM of different lignocellulosic materials, also observed uniformity in burning and mass loss of the materials.

By a detailed analysis of the Figure 2, it can be observed that the treatments T4 and T3 had the highest and the lowest averages temperatures, respectively. The highest final temperature from the T5 treatment (I00\% eucalyptus wood) test (Figure 2) may be related to its greater bulk density (Table I), which favored a better accommodation and allowed for an efficient transfer of energy in order to constitute a "continuous block" of mass in combustion. In practical terms, there was a joint burning that was uniform and connected in the heat supply.

Figure IB shows that the treatment with $50 \%$ WWU (T3 treatment) presented similar behavior to the other treatments, differing in that it used less time for the consumption of the total mass in generation of heat ( $\pm 15 \mathrm{~min}$ ). According to Quirino and Brito (199I), it is relevant that a certain constant temperature occurs, and abrupt variations require frequent interferences in the process (e.g. feedback) to maintain the level of combustion. It was observed that the T2 treatment had complete degradation approximately 14 minutes after the test started, while the remaining treatments reached total degradation only after 25 minutes of test time (Figure IB). This was favored by the high temperatures obtained by this composition throughout the test.

The maintenance of the temperature at values $\geq$ $150{ }^{\circ} \mathrm{C}$ is of great relevance, considering the calculations from Equation 2. In fact, the T5 treatment of only eucalyptus wood visibly had the largest area under the curve (Figure IA) and, consequently, the highest ICOM (Figure 2).

The ICOM values for the T2, T3, T4, and T5 treatments are in agreement with the values obtained by Quirino and Brito (199I) for several densified lignocellulosic fuels ( 0.30 to I.23). It is considered that the larger the ICOM, the greater the heat generation and the lower mass consumption of the fuel in relation to the time.

In general, if a fuel releases enough energy (amount of heat) during combustion, but consumes a lot of mass to generate it, its ICOM will be lower. This occurred for treatment T3, which had an ICOM lower than treatment T4 as a result of providing high temperatures (Figure IA), but lower percentage mass loss (Figure IB). Treatments that presented significant proportions of WWU (T2 and T3) had the third largest ICOM, being greater only in relation to treatment $\mathrm{TI}$ (I00\% WWU).

Based on the observed behavior, it is expected that the low bulk density and the extractive content favor the formation of high temperatures for wood fuels, and this, consequently, increases the transfer of energy of the mass under combustion, which favors the greater mass loss. This can be proven by Dias Júnior et al. (20l4), whom obtained higher rates of degradation $\left(\mathrm{g} \cdot \mathrm{min}^{-1}\right)$ for lower density fuels. The higher content of volatile materials in the fuel improves the ability of the material to generate flames (BRITO et al., 1987; ANDRADE; GONÇALVES, 1999). Further research should be conducted to clarify this possible relationship.

The results obtained suggest that, in fact, there are arguments to consider the addition of eucalyptus wood to WWU as a relevant characteristic, for use in combustion and direct burning. In the same sense, the control of eucalyptus wood could be proposed to define compositions, depending on the type of behavior that is desired and being modified for the type of heat demanded. Given the need for improved use of WWU (other than disposal in landfills), WWU intermediary formulations with eucalyptus wood (exemplified in treatment T3) resulted in significant increases in energy characteristics.

For example, in situations requiring the presence of flames during heating, such as in furnaces of stills and boilers in addition to pottery fields, it is recommended to use fuels with the highest volatile materials (DIAS JÚNIOR et al., 20 14). According to the authors, the most used are those with the greatest capacity to stay lit, e.g., with the lowest possible mass consumption in situations where flame formation is not recommended during heating, such as fireplaces and forges. For this, the treatments T3, T4 and T5 would be those recommended. 
On the other hand, the composition of treatments T2 and T3 (75\% WWU and 50\% WWU, respectively) presented an improved ICOM, as shown in Figure 2. This occurred with even small additions of eucalyptus wood, resulting in increased energetic value production.

These aspects raise the need for new studies, combining the combustion quality of the material, optimum temperature ranges, and the quantification of diverse materials that can be tested for this use. Emissions of heavy metals into air may occur as the combustion temperature are reached, as each element exhibits distinct properties at the boiling point, and this should also be considered (KROOK et al., 2004; KROOK et al., 2006).

\section{Estimates of variables and cluster analysis}

Table 2 shows the correlations obtained (consonance for prediction of energy variables). However, due to the focus on the addition of eucalyptus wood to the WWU, only significant observed relationships involving the proportion of the materials were highlighted in the study.

The addition of eucalyptus wood provided a significant positive relation with bulk density, volatile material content, and combustion index (ICOM). In contrast, there were negative correlations for ash content, fixed carbon content, and mineral contamination rate (Table 2). The significance of these relationships makes it possible to estimate the properties of some variables as a function of the addition of eucalyptus wood, yet still observe the characteristics of the WWU collected.

The adjustments made better estimation models possible as illustrated in Figure 3 . The $\mathrm{R}^{2}$ values were improved for the bulk density, volatile material content, ash content and ICOM variables, allowing for better estimation of these properties (Figure 3).
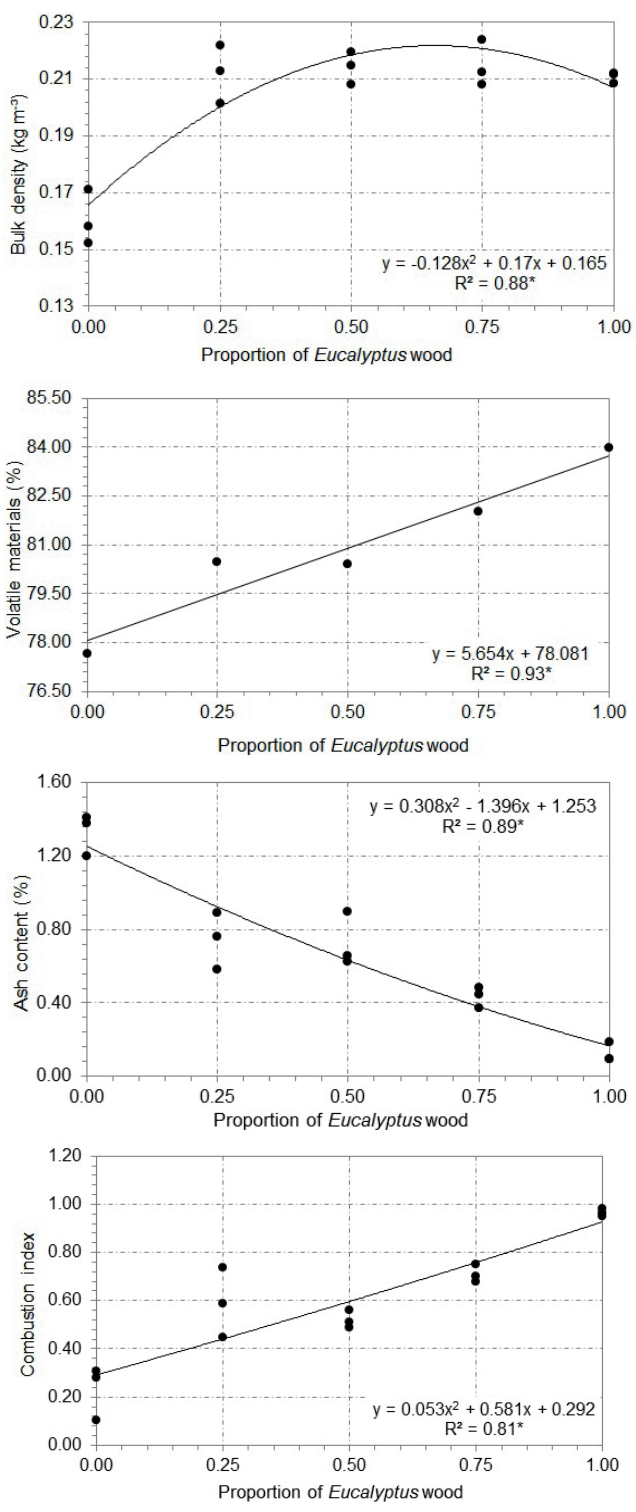

FIGURE 3 Adjusted models the significant properties of the treatments analyzed.

TABLE 2 Data correlation matrix for the variables analyzed.

\begin{tabular}{|c|c|c|c|c|c|c|c|c|c|c|c|}
\hline Variable & PEW & BM & EC & LC & $\mathrm{TH}$ & VM & $A C$ & $\mathrm{FC}$ & $\mathrm{HHV}$ & LHV & $C R$ \\
\hline PEW & I & - & - & - & - & - & - & - & - & - & - \\
\hline $\mathrm{DB}$ & $0.66 *$ & I & - & - & - & - & - & - & - & - & - \\
\hline EC & -0.46 & -0.52 & 1 & - & - & - & - & - & - & - & - \\
\hline LC & -0.32 & -0.01 & -0.09 & I & - & - & - & - & - & - & - \\
\hline $\mathrm{TH}$ & 0.08 & -0.21 & 0.50 & $-0.91 *$ & 1 & - & - & - & - & - & - \\
\hline VM & $0.82 *$ & $0.68^{*}$ & -0.37 & -0.21 & 0.03 & 1 & - & - & - & - & - \\
\hline$A C$ & $-0.94 *$ & $-0.75^{*}$ & $0.62 *$ & 0.12 & 0.16 & $-0.87^{*}$ & I & - & - & - & - \\
\hline $\mathrm{FC}$ & $-0.78 *$ & $-0.65^{*}$ & 0.31 & 0.23 & -0.07 & $-0.99 *$ & $0.8 I^{*}$ & I & - & - & - \\
\hline $\mathrm{HCV}$ & 0.021 & 0.27 & -0.23 & 0.26 & -0.32 & 0.04 & -0.21 & -0.01 & I & - & - \\
\hline LCV & 0.021 & 0.27 & -0.23 & 0.26 & -0.32 & 0.04 & -0.21 & -0.01 & 1.00 & I & - \\
\hline CR & $-0.76 *$ & -0.38 & $0.59 *$ & 0.45 & -0.14 & $-0.68^{*}$ & $0.74 *$ & $0.65 *$ & 0.069 & 0.07 & 1 \\
\hline ICOM & $0.90 *$ & $0.7 I^{*}$ & $-0.57 *$ & -0.28 & 0.00 & $0.78 *$ & $-0.92 *$ & $-0.73 *$ & 0.14 & 0.14 & $-0.70 *$ \\
\hline
\end{tabular}

Where: PEW=Proportion of eucalyptus wood; $B M=$ bulk density $\left(\mathrm{kg}^{-3} \mathrm{~m}^{-3}\right) ; \mathrm{EC}=$ extractive content $(\%) ; \mathrm{LC}=$ lignin content $(\%) ; \mathrm{HC}=$ holocellulose content $(\%)$; $\mathrm{VM}=$ volatile materials (\%); $\mathrm{AC}=$ Ash content (\%); $\mathrm{FC}=$ fixed carbon content (\%); $\mathrm{HHV}=$ higher heating value $\left(\mathrm{MJ} \cdot \mathrm{kg}^{-1}\right) ; \mathrm{LHV}=$ lower heating value $\left(\mathrm{MJ} \cdot \mathrm{kg}^{-1}\right)$; $\mathrm{CR}$ $=$ contamination rate $(\%)$; ICOM=combustion index. 
For the bulk density, volatile materials content, and ICOM, the increase in the proportion of eucalyptus wood in the treatment allowed for the increase of these variables and the decrease of ash content. These properties are important not only from an energy point of view, but can also guide the choice, selection, and supply of these types of materials, e.g., models can assist in economic decisionmaking for those involved in the sector.

Figure 4 shows the dendrogram obtained by the cluster analysis (HCA). The formation of three distinct clusters is observed, considering the cutoff point on the distance scale, which is equivalent to $60 \%$ of the total similarity, Where: Proportion of WWU/eucalyptus wood (\%): TI = I00/0; T2 = 75/25; T3 = 50/50; T4 = 25/75; $\mathrm{T} 5=0 / 100$.

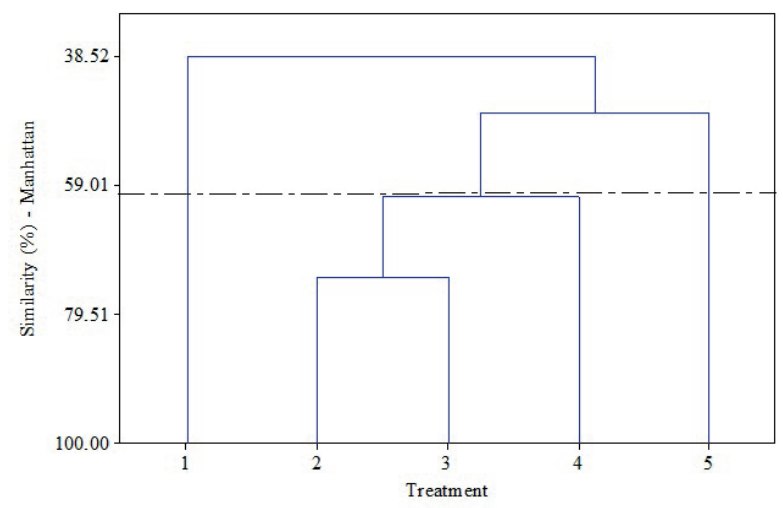

FIGURE 4 Dendrogram of cluster analysis.

Cluster I was formed by treatment TI (100\% WWU), while the cluster 2 was formed by treatments T2, T3, and T4 (25\%, 50\% and 75\% WWU, respectively), and cluster 3 was formed by the T5 treatment, composed only of eucalyptus wood.

The cluster composed of TI treatment (cluster I) was the least favorable for energy production. It can be observed that the composition of this cluster had high ash content, contamination rates, and low bulk density, factors considered limiting for energy use (Table I). The low bulk density observed for cluster I may negatively influences in the volumetric heating value $\left(\mathrm{MJ} \cdot \mathrm{m}^{-3}\right)$, e.g., in the amount of energy per unit volume of the combustible material (PROTÁSIO et al., 20I3).

The cluster formed by the treatments T2, T3, and T4 (cluster 2) was classified as an intermediate for production of energy, as presented, on average, advantageous values of bulk density, heating value, and high volatile material contents (Table I). The values for volatile materials obtained for cluster 2 suggest the ease of ignition and the generation of flames/flares from the material (DIAS JÚNIOR et al., 20I4; DIAS JÚNIOR et al., 2015).

Cluster 3, formed by the treatment T5 (100\% eucalyptus wood), was distinguished by characteristics favorable for energy use, due to high values of bulk density, volatile material content, heating value, low extractive content, ash content, and mineral contamination rate (Table I).

\section{CONCLUSIONS}

The best combustion performance, as a function of ICOM, was observed for treatment T5 (I00\% wood eucalyptus), and the worst condition was treatment TI (100\% WWU).

Significant correlations between the studied variables were detected, making the generation of models possible for the estimation of easily measured properties.

The cluster analysis allowed for the determination of the best treatments for energy production.

In general, the results showed that the use in equal proportions of solid residues and eucalyptus wood resulted in significant increases in the characteristics analyzed for energy production. Thus, treatment T3 is the most recommended for this purpose.

\section{ACKNOWLEDGMENTS}

The authors acknowledge the Brazilian Government Agency of Coordination for the Improvement of Higher Education Personnel (CAPES), the Institute of Forestry Research and Studies (IPEF) and the National Council for Scientific and Technological Development (CNPq/I42075/2016-7) for the scholarship grants awarded. We would also like to thank Michael James Stablein of the University of Illinois Urbana-Champaign for his translation and English revision services in this research.

\section{REFERENCES}

ANDRADE, C. R. A bola da vez. Opiniões. Ribeirão Preto. v. 99, 2014. Disponível em: http://florestal.revistaopinioes. com.br/revista/detalhes/7-bola-da-vez/> ANDRADE, A. M.; GONÇALVES, F. G. Adaptação de um forno para o aproveitamento dos subprodutos da carbonização. Revista Árvore, v. 23, n. 2, p. 24I-247, 1999.

ANDRADE, A. M. Influência da casca de Eucalyptus grandis W. Hill ex Maiden no rendimento e qualidade de carvão vegetal. 1989. 86 f. Dissertação (Mestrado em Ciências Florestais) - Universidade Federal de Viçosa, Viçosa, 1989.

ASSOCIAÇÃO BRASILEIRA DE NORMAS TÉCNICAS. NBR 8633: Carvão vegetal - Determinação do poder calorífico Método de ensaio. Rio de Janeiro, 1984. 13p. 
ASSOCIAÇÃO BRASILEIRA DE NORMAS TÉCNICAS. NBR 8I 12: carvão vegetal - análise imediata. Rio de Janeiro, 1986. $5 p$.

ASSOCIAÇÃO BRASILEIRA DE NORMAS TÉCNICAS. NBR 10.007: amostragem de resíduos. Rio de Janeiro, 2004. 25p.

ASSOCIAÇÃO BRASILEIRA DE NORMAS TÉCNICAS. NBR 6922: Carvão vegetal - ensaios físicos determinação da massa especifica (densidade à granel). Rio de Janeiro, ABNT, 198I. 25p.

ATKINS, R. S.; DONOVAN, C. T. Wood Products in the waste stream: characterization and combustion emissions. Technical report. U.S. Environmental Protection Agency, Washington, D. C. EPA/600/R-96/I I9a, 1996. Disponível em: < https://www3.epa.gov/ttn/catc/dirl/wood_waste. pdf $>$. Acesso em I4 de março de 2016 .

BOND, T. C.; DOHERTY, S. J.; FAHEY, D. W.; FORSTER, P. M.; BERNTSEN, T.; DEANGELO, B. J.; FLANNER, M. G.; GHAN, S.; KÄRCHER, B.; KOCH, D.; KINNE, S.; KONDO, Y.; QUINN, P. K.; SAROFIM, M. C.; SCHULTZ, M. G.; SCHULZ,M.; VENKATARAMAN, C.; ZHANG, H.; ZHANG, S.; BELLOUIN, N.; GUTTIKUNDA, S. K.; HOPKE, P. K.; JACOBSON, M. Z.; KAISER, J. W.; KLIMONT, Z.; LOHMANN, U.; SCHWARZ, J. P.; SHINDELL, D.; STORELVMO, T.; WARREN, S. G.; ZENDER, C. S. Bounding the role of black carbon in the climate system: a scientific assessment, JGR Atmos., n. I I8, v. I I, p. 5380-5552, 2013.

BRAND, M. A. Energia da biomassa florestal. Editora Interciência. Rio de Janeiro, 20I0. II4 p.

BRITO, J. O.; TOMAZELLO FILHO, M.; SALGADO, A. L. B. Produção e caracterização do carvão vegetal de espécies e variedades de bambu. IPEF, n. 36, p. 13-17, 1987.

BRITO, J. O.; CERIBELLI, U. L. Determinação de contaminantes sólidos não combustíveis em biomassa: Procedimento de Avaliação. Grupo de Pesquisa em Bioenergia e Bioprodutos de Base Florestal. Piracicaba: USP/ESALQ, 2012.

CALVO, A. I.; TARELHO, L. A. C.; ALVES, C. A.; DUARTE, M.; NUNES, T. Characterization of operating conditions of two residential wood combustion appliances. Fuel Processing Technology, n. I26, p. 222-232, 2014.

DIAS JÚNIOR, A. F; ANDRADE, A. M.; COSTA JÚNIOR, D. S. Caracterização de briquetes produzidos com resíduos agroflorestais. Pesquisa Florestal Brasileira, v. 34, n. 79, p. 225-234, 2014.

DIAS JÚNIOR, A. F; BRITO, J. O.; ANDRADE, C. R. Granulometric influence on the combustion of charcoal for barbecue. Revista Árvore, v. 39, n. 6, 2015.

FARAGE, R. M. P.; REZENDE, A. A. P.; SILVA, C. M.; NUNES, W. G.; CARNEIRO, A. C. O.; VIEIRA, D. B.; RODRIGUES, C. L. S. Avaliação do potencial de aproveitamento energético dos resíduos de madeira e derivados gerados em fábricas do polo moveleiro de Ubá - MG. Ciência Florestal, v. 23, n. I, p. 203-2I2, 2013.
FIDAN, M. S.; YASAR, S. S.; YASAR, M.; ATAR, M.; ALKAN, E. Effect of seasonal changes on the combustion characteristics of impregnated cedar (Cedrus libani A. Rich.) wood. Construction and Building Materials, v. 106, p. 7II-720, 2016.

KRISTJANSSON, K.; NAESS, E.; SKREIBERG, O. Dampening of wood batch combustion heat release using a phase change material heat storage: Material selection and heat storage property optimization. Energy, v. I5, n. I, p. 378-385, 2016.

KROOK, J.; MARTENSSON, A.; EKLUND, M. Metal contamination in recovered waste wood used as energy source in Sweden. Resources, Conservation and Recycling, v. 4I, n. I, p. I-I4, 2004.

KROOK, J.; MÂRTENSSON, A.; EKLUND, M. Sources of heavy metal contamination in Swedish wood waste used for combustion. Waste Management, v. 26, n. 2, p. 158I66, 2006.

MANLY, B. J. F. Métodos estatísticos multivariados: uma introdução. 3ed. Bookman. Porto Alegre, 2008.

MATTOS, R. L. G.; CHAGAS, F. B.; GONÇALVES, R. M. Painéis de madeira no Brasil: panorama e perspectivas. BNDES Setorial, Rio de Janeiro, n. 27 , p. I2I-I56, 2008.

MINGOTI, S. A. Análise de dados através de métodos de estatística multivariada: uma abordagem aplicada. Belo Horizonte: UFMG, 2005. 297 p.

MINITAB, Inc. Minitab statistical software ${ }^{\mathrm{TM}}$, Release 16.0, Copyright $^{\odot}, 2010$.

MINISTÉRIO DO MEIO AMBIENTE (MMA). Levantamento sobre a geração de resíduos provenientes da atividade madeireira e proposição de diretrizes para políticas, normas e condutas técnicas para promover o seu uso adequado, 2009. 35p.

NOLASCO, A. M.; ULIANA, L. R. Gerenciamento de resíduos na indústria de pisos de madeira. Ed. I, Piracicaba: Associação Nacional de Pisos de Madeira, 2014. 40p.

PAULA, L. E. R.; TRUGILHO, P. F.; REZENDE, R. N.; ASSIS, C. O.; BALIZA, A. E. R. Produção e avaliação de briquetes lignocelulósicos. Pesquisa Florestal Brasileira, v.3I, n.6I, p. $103-112,2011$.

PROTÁSIO, T. P.; BUFALINO, L.; GUIMARÃES JUNIOR, M.; TONOLI, G. H. D.; TRUGILHO, P. F. Técnicas multivariadas aplicadas à avaliação de resíduos lignocelulósicos para a produção de bioenergia. Ciência Florestal, v. 23, n. 4, p. 77I-78I, 2013.

QUIRINO, W. F.; BRITO, J. O. Características e índice de combustão de briquetes de carvão vegetal. Brasília: Laboratório de Produtos Florestais - LPF (Série Técnica 13), 1991. 14 p. 
QUIRINO, W. F.; VALE, A. T.; ANDRADE, A. P. A.; ABREU, V. L. S.; AZEVEDO, A. C. S. A. Poder calorífico da madeira e de materiais lignocelulósicos. Biomassa \& Bioenergia, v. I, n.2, 73-I82, 2004.

REIS, L. B. Geração de energia elétrica. Ied: Manole, São Paulo, 20I5. 46Ip.

REMADE SCOTLAND. Woodwaste arisings in Scotland: assessment of available data on scottish wood waste arisings. Glasgow - Scotland. 3ed. Drumond House, 2004. 23p.

SOARES, V. C.;BIANCHI, M. L.; TRUGILHO, P. F.; PEREIRA, A. J.; HOFLER, J. Correlações entre as propriedades da madeira e do carvão vegetal de híbridos de eucalipto. Revista Árvore, v. 38, n. 3, p. 543-549, 2014.

TECHNICAL ASSOCIATION OF PULP AND PAPER TAPPI 222 05-74. Industry lignin in wood. 1974.
TECHNICAL ASSOCIATION OF PULP AND PAPER - TAPPI- 2 05-75. Industry preparation of wood for chemical analysis (Including procedures for removal of extractives an determination of moisture content). 1975.

SOUZA, S. S.; SANATOS, P. O.; VAREJÃO, M. J. C.; NASCIMENTO, C. C. Detecção do teor de cinzas e sílica em materiais lignocelulósicos. In: Anais... da $6 I^{\mathbf{a}}$ RBPC. Reunião Anual da Sociedade Brasileira de Progresso da Ciência. Manaus - AM, 2009.

Disponível em: < http://www.sbpenet.org.br/livro/6 I ra/resumos/ resumos/5044.htm >. Acesso em: I4 de maio de 2015.

WIECHETECK, M. Aproveitamento de resíduos e subprodutos florestais, alternativas tecnológicas e propostas de políticas ao uso de resíduos florestais para fins energéticos. Sumário Executivo. Ministério do Meio Ambiente. Curitiba, 2009. 